\title{
メチルメタアクリレート・ブタジェン共重 合体ラテックスの顔料塗被紙における応用*
}

1. 緒

最近コーテット紙の伸びはその機能と付加価值の高 さから飛躍的なものとなり，ここ数年日本に沶いて印 刷に使用されるコーテッド紙の需要と生産は急激に增 加してきた。そしてこのオンマシーンまたはオフマシ ーンに適用されるピグメントコーティング用としてカ ゼインまたは澱粉のラテックスによる部分置換は重要 な地位を占め, このようにピグメントバインダーに使 用されるラテックス・エマルジョンは，メチルメタア クリレート・ブタジェン共重合体ラテックス，スチレ ン・ブタジェン共重合体ラテックス，アクリル酸エス テルエマルジョン，䤀酸ビニル系エマルジョンなどが あり, 普通, ラテックス・エマルジョンはカゼイン㐫 るいは測粉の 20 50\%（乾燥重量）をラテックスで 置き換えて用いる。特にメチルメタアクリレート・ブ タシェン共重合体ラテックスはピグメントコーティン グにすぐれた性能を示し, 安定度, 機能の高い印刷用 コーテッド紙つ製造に適し，わが国でもすでに定評が あり多くの需要を充たしてきた。以下メチルメタアク リレート・ブタジェン共重合体ラテックスの性質, 効 果, 応用加工法などについて概説したいと思う。

2.メチルメタアクリレート・フタジェン共重合体 ラテックスのピグメントコーティンク用バイン ダーとしての一般的性質

(1) ラテックスの粒径

粒径は小さければ小さい汪どピッキング抵抗は上 昇するが $0.1 \mu \sim 0.18 \mu$ では差が 見られず $0.18 \mu \sim ~$ $0.27 \mu$ でピッキング抵抗は若干落ちる。 $0.27 \mu$ 以上 ではピッキング抵抗は急激に低下する。

(2) ブタジェン含量

ブタジェン含量が多ければ多いほどピッキング抵 抗は上昇するが，メチルメタアクリレートの減少に より光沢は低下寸る。

(3) カルボキシル化ラテックス カルボキシル化\%の増加汇従いピッキング抵抗は

* 原稿受付 $40,3.18$

** 東洋高压工業株式会社 商品技術研究所

昭和 40 年 7 月
福田敏宏**

上昇するが $5 \%$ \%が限界である。カルボキシル化した ものは凍結安定性, 澱粉混和性が良くなる。

(4) 乳化 剂

ノニオン界面活性剤の量の増加によりピッキング 抵抗は低下するが，アニオン界面活性剤量について はあまり影響しない。

(5) ラテックスの表面張力 表面張力の低下に従い泡立ち傾向が大さくなる。

(6) ラテックスの粘度

特に著しい作用はない。

（7）ラテックスの機械的安定性

機械的安定性が低下するとピッキング抵抗は低下 する。メチルメタアクリレート・ブタジェン共重合 体ラテックスの一般的性質

\begin{tabular}{|c|c|}
\hline 固 & $47.5 \%$ \\
\hline 比 & $1.03\left(25^{\circ} \mathrm{C}\right)$ \\
\hline 粘 & 約 $22 \operatorname{cps}\left(20^{\circ} \mathrm{C}\right)$ \\
\hline $\mathrm{pH}$ & $6 \sim 7$ \\
\hline 表 面 張 & 37.5 dyne $/ \mathrm{cm}\left(25^{\circ} \mathrm{C}\right)$ \\
\hline 平 均 粒. 子径 & $0.15 \mu$ \\
\hline MMA/ブタジェン! & $62 / 38$ \\
\hline
\end{tabular}

\section{3、メチルメタアクリレート・フタジェン共重合体 ラテックスの効果}

メチルメタアクリレート・ブタジェン共重合体ラテ ックスをコーティングカラーに配合した場合つぎのよ らな利点が得られる。

(1) 塗被固形分の増加

(2) ピッキング抵抗の向上

(3) ウ土ットラブの向上

(4) カレンダー光沢の向上

(5) 二ス引き光沢の向上

(6) ワックス保持力の改善

（7）塗被膜の柔軟性の向上

(8) インキ受理性の改善

（9）印刷適性の向上

上記各項目について以下説明を加える 
(1) 塗 被 固 形 分

塗被可能な固形分の最大值はそのカラーの粘度によ って大きく影暃を受ける。高い固形分含有量のもとで しかも良好な流動性，作業性を得ることが最も好まし く，カラー中のバインダーの50\%をラテックスで置き 換えた場合コートできる固形分は約 $8 \%$ 増加でき，さ らにラテックスの割合を増すとコート可能固形分はま だかなり増加できる。

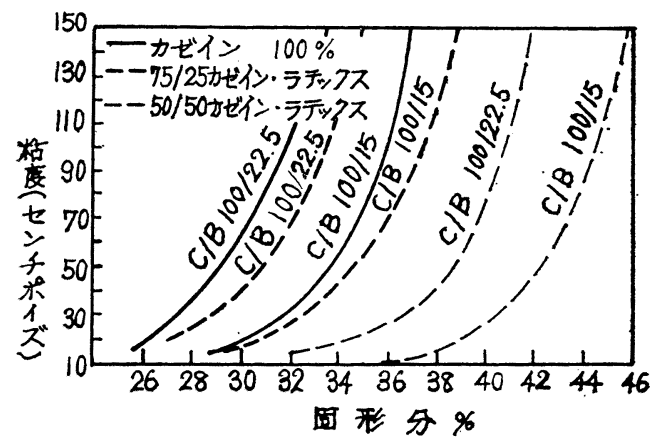

第 1 図 固形分濃度と粘度の関係

(2) ピッキング抵抗

カゼインあるいは澱粉をメチルメタアクリレート・ ブタジェン共重合体ラテックスで置き換えた場合，コ ーテッド紙の表面強度に著しい向上が認められる。こ のことは I.G.T 印刷適性試験機や宮腰式印刷試験機で すでに立証されている。ピッキング抵抗はコーテッド 紙を通常の条件で貯蔵した場合熟成（Ageing）によ りさらに向上する。

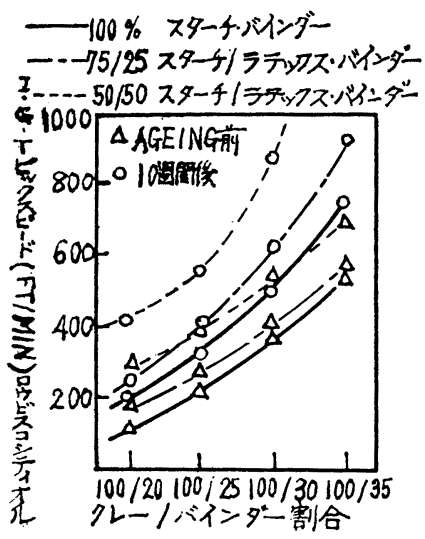

第 2 図 バインダー量と I.G.T. ピックの関係

(3) ウェットラブ

カラー中のカゼインあるいは澱粉の一部をメチルメ タアクリレートブタジェン共重合体ラテックスで置き 換えるとコート面の耐水性が改善される。カゼインの 25\%またはそれ以上の量をラテックスで置き換えると

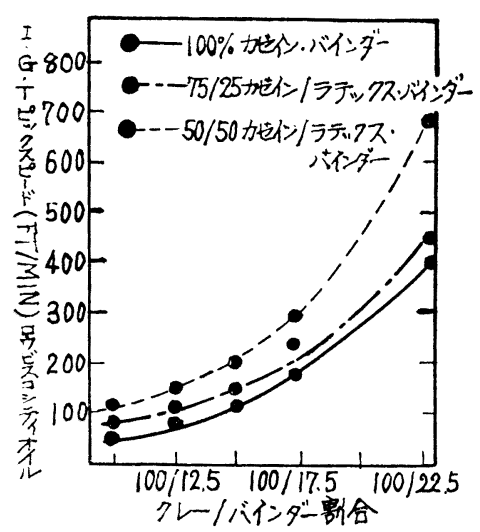

第 3 図 バインダー量とI.G.T.ピックの関係 耐水性が増し，カゼインの硬化剂としてフォルムアル デヒドを用いる必要はない。耐水性はカゼインバイン ダーのときより潵粉バインダーのときの方がとくに要 求される。澱粉バインダーのとき初期に括いて改善の 程度はあまり著しくないがコーテッド紙を数週間貯蔵 したあとでは耐水性は改善される。

(4) カレンダー光沢

メチルメタアクリレート・ブタジェン共重合体ラテ ックスをカゼインまたは澱粉バインダーに配合すると カレンダー掛け後の光沢に顕著な改良のあとが見られ る。これはメチルメタアクリレートブタジェン共重合 体が熱可塑性であるため，カレンダー操作中にその一 部が若干流動性を帯びるようになるためであると考え られている。したがって通常のカレンダー操作で普通

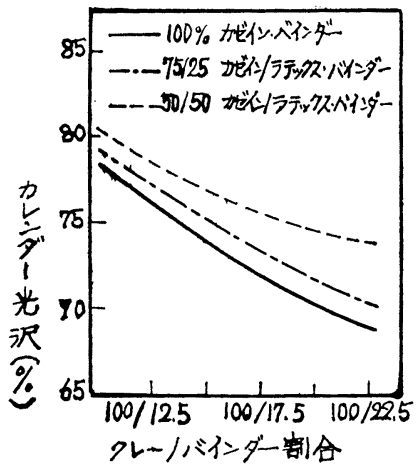

第 4 図 バインダー量とカレンダー光沢の関係

以上の光沢が得られ，またカレンダー压をへらした場 合でも通常の光沢を得ることができる。またラテック スは光沢を向上させる以外に紙の表面に感触のよいビ ロードのような風合を与える。

(5) ニス引き光沢

通常良好な二ス引き光沢を得るにはコーテッド紙の 


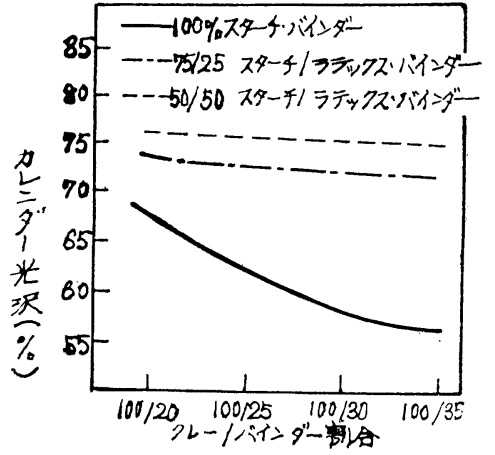

第 5 図 バインダー量とカレンダー光沢の関係

表面を緻密に仕上げるためにバインダーの配合量を多 くする必要がある。しかしカゼインや澱粉の一部をメ チルメタアクリレートブタジェン共重合体ラテックス で置さ換えると，コート面が二ス液の浸透に対して強 い抵抗を持つためニス引き光沢が向上し裏抜けが少く なり，ひいてはバインダーの配合量を減ずることも可 能である。スチレンブタジェン共重合体ラテックスよ りもメチルメタアクリレートブタジェン共重合体ラテ ックスの方がニス引き光沢の良いのが特長である。

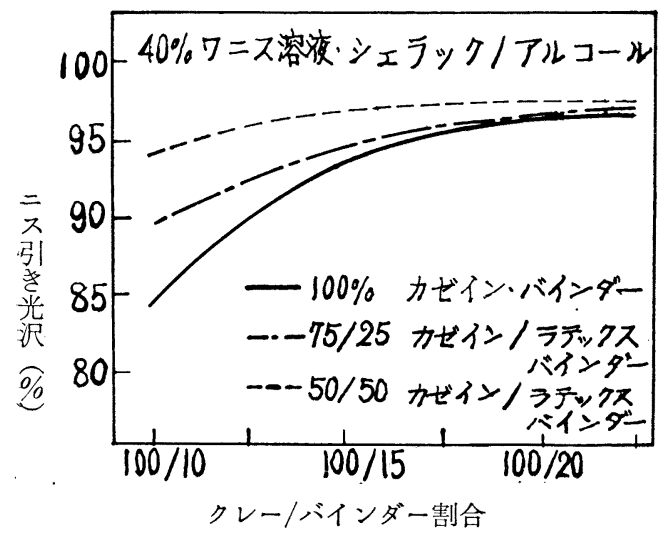

第 6 図 バインダー量とニス引き光沢の関係

(6) ワックス保持力

カラーにメチルメタアクリレート・ブタジェン共重 合体ラテックスを配合すると，ワックス保持力が改善 されて透明化する傾向が減少し印刷性の低下を最小限 に止めることができる。

（7）塗被膜の柔軟性

メチルメタアクリレート・ブタジェン共重合体は柔

あ軟性に富むバインダーであるから，澱粉やカゼインの 一部をラテックスで置き換えると，塗被膜の柔軟性が 増大する。このことは折り目の部分でコート面が粉末 状になって剥がれたり，截断時に生ずる塵の減少によ

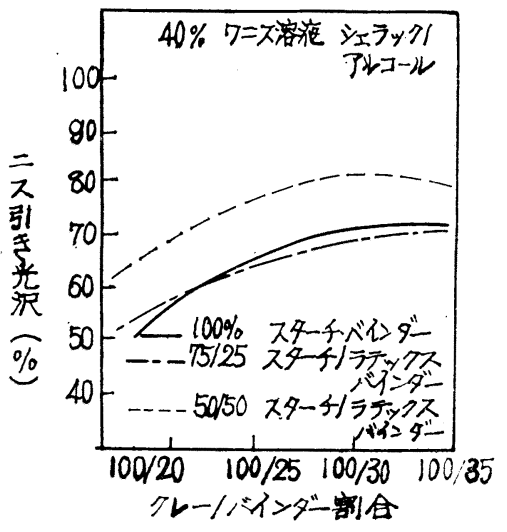

第7図 バインダー量とニス引き光沢の関係 っても明らかである。

(8)インキ受理性

メチルメタアクリレートブタジェン共重合体ラテッ クスのインキ受理性に拉よぼす試験データはPATRA 吸油度およびI.G.T.インキ吸収浸透時間で測定した。 カゼインカラーの場合，カゼインをラテックスで置さ 換觉ると吸油時間で增加し，この度合はラテックス 25 \%まで比較的小さくラテックスの分量がそれ以上にな るに従い大きくなる。澱粉カラーの場合はラテックス の効果がやや異なり，澱粉をラテックスに置き換え ていくにしたがって吸油時間が減少しラテックスが 25～30\%を越光るとふたたび増大してラテックス $50 \%$ で澱粉単独の場合とほぼ同等となる。以上の結果は PATRA, I.G.T. ともに同様である。

通常澌粉をバインダーとしたコーテッド紙に見られ る欠点はインキのベヒクルが原紙に吸い込まれるまで に時間が掛りすぎることであるが，ラテックスを使用 した場合には，このよらな心配がなく，このことはと くにグラビア印刷にはかなり重要なことである。

（9）印刷適性

ピグメントコート・バインダーとしてメチルメタア クリレート・ブタジェン共重合体ラテックスを使用し た場合，印刷適性が向上し，容易に所望の印刷適性が 得られる。またこのラテックスはカゼイン配合量を多 くした場合に起こりがちな光沢またはインキ受理性の 劣化などの欠陷を最少限に止める効果がある。

4. コーテッド紙に応用した場合のメチルメタアク リレートブタジェン共重合体ラテックスのスチレ ンブタジェン共重合体ラテックスに対する優位点

（1）ワニス光沢が良いこと

(2) メチル・メタアクリレートを含むため耐光性が優 れていること。 


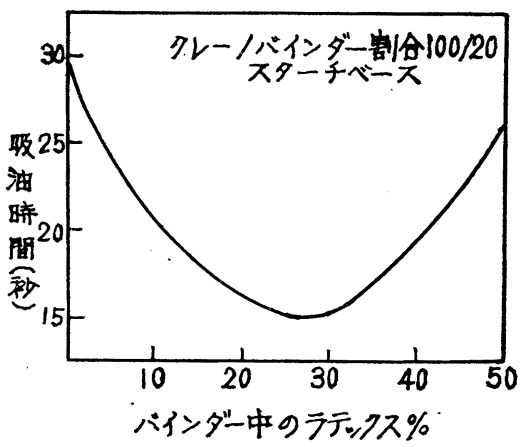

第 8 図 PATRA 吸油時間とラテックス量の関係

\begin{tabular}{|c|c|c|}
\hline & $\begin{array}{c}\text { カゼイン } \\
\text { ラテックス }\end{array}$ & $\begin{array}{c}\text { 澱 } \\
\text { ラテックス }\end{array}$ \\
\hline MMA・ブタシェン系 & $70.4 \%$ & $41 \%$ \\
St. ブタジェン系 & 59.0 よ゚ & $31 \%$ \\
\hline
\end{tabular}

(シェラック 40\%アルコール溶液によるニス引き光沢\%)

の 2 点があげられる。

5. メチル・メタアクリレートブタジェン共重合体 ラテックスの応用

メチルメタアクリレート・ブタジェン共重合体ラテ ックスを使用する場合，一般のラテックスと同様に取 り扱いには別段従来のカラー混合法を変更する必要は ない。普通ラテックスはカゼインあるいは濒粉の 20 ～ $50 \%$ (乾燥重量) をラテックスで置き換えて用いる。

(1) チャンピオン・オンマシンコーティング

ラテックスに適しているマシンコーティング法は, チャンピオンロールとドクターナイフを用いる方式 である。以下ラテックスをチャンピオンコーターに 使用した場合の配合例を示すが，通常このようなカ ラーはカゼインをベースとしているが，場合によっ ては澱粉をベースにすることもある。

(2) 高濃度オンマシンコーティング

コンソリデーテッド (Massey) 方式などの方法 で，高濃度コーティング $(60 \sim 65 \%)$ を行なう場合 にラテックスの使用は，次のような配合が提案され ている。

\begin{tabular}{|c|c|c|}
\hline ク & $v$ & - \\
\hline 澱 & & 粉 \\
\hline $\bar{~}$ & м & $\pi$ \\
\hline
\end{tabular}

(3) サイズ・プレス・コーティング

紙の表面に澱粉溶液を塗布して表面のケバ立ちの 防止, 原紙の表面強度の強化耐油性の増強の目的で サイズプレスは広く採用されている。このような加 工の場合，澱粉にラテックスを澱粉の10～30\%を置 き換えてよい結果を得たが，ピグメント入りのサイ
チャンピオン オンマシンコーテング用配合例

\begin{tabular}{|c|c|c|c|c|}
\hline \multirow{2}{*}{ カゼインベース } & \multicolumn{2}{|c|}{ レタープレス } & \multicolumn{2}{|c|}{ オフセット } \\
\hline & 乾燥 & & 乾 & 湿潤量 \\
\hline クレー（固形分 $60 \%$ ) & 100 & 167 & 100 & 167 \\
\hline カルゴン $(60 \%$ クレー中 $)$ & 0.5 & - & 0.5 & - \\
\hline 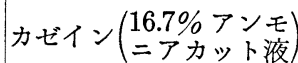 & 10 & 60 & 12.5 & 75 \\
\hline ラテックス $\left(\begin{array}{l}\text { 固形分 } \\
47.5 \%\end{array}\right)$ & 4 & 8.4 & 5.0 & 10.5 \\
\hline 水 & - & 16.5 & - & 26 \\
\hline 全 固 形 分 \% & - & 45 & - & 42.5 \\
\hline
\end{tabular}

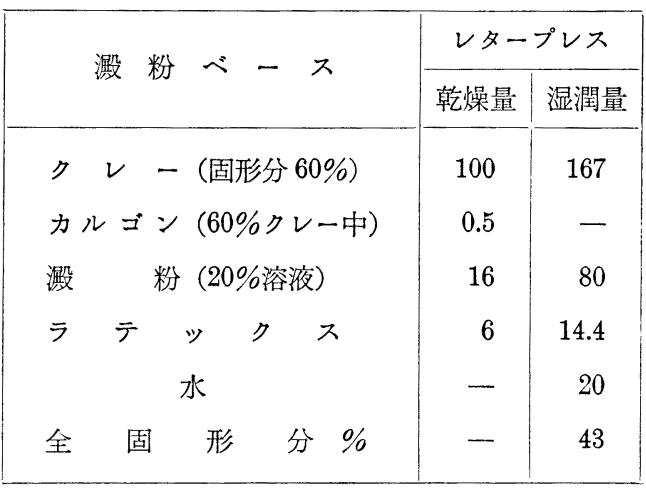

ズプレス用の配合にラテックスを用いた場合に，も っともよい結果が得られると考劣られる。このコー ティングは二つの目的を達するもので, 原紙のサイ ズをおこならとともに紙の表面の凹凹をピグメント で充填する。このような方法は印刷用紙の仕上げ工 程やオフマシン・コーティング用原紙の下塗り工程 にも興味深い方法である。

次に揭げる配合例はピグメント入りのサイズプレ スコーティング用の調製法であるが，実際に用いる 場合にはコーターの種類や原紙の性質に合わせる必 要がある。

\begin{tabular}{|c|c|c|c|c|}
\hline & \multicolumn{2}{|c|}{ I } & \multicolumn{2}{|c|}{ II } \\
\hline & $\begin{array}{l}\text { 乾燥 } \\
\text { 重量 }\end{array}$ & \begin{tabular}{|l} 
湿潤 \\
重量:
\end{tabular} & $\begin{array}{l}\text { 乾燥 } \\
\text { 重量 }\end{array}$ & $\begin{array}{l}\text { 湿潤 } \\
\text { 重量 }\end{array}$ \\
\hline クレー（固形分 $60 \%$ ) & 100 & 167 & 100 & 167 \\
\hline カルゴン $(60 \%$ クレー中 $)$ & 0.5 & - & 0.5 & 一 \\
\hline 澱 粉 (20\%溶液) & 22.5 & 112.5 & 12.5 & 62.5 \\
\hline (カ デ゙イン学定化 $41.6 \%$ & 7.5 & 18.0 & $12 . \check{5}$ & 30 \\
\hline 水 & $75-$ & 137 & 98 & 158 \\
\hline 全 固 形 分 \% & $30-$ & 35 & 30 & 35 \\
\hline 使用温度 $40^{\circ} \mathrm{C} \sim 50^{\circ} \mathrm{C}$ & - & 一 & - & - \\
\hline 塗被量(片面) $3 \sim 5 \mathrm{~g} / \mathrm{m}^{2}$ & 一 & 一 & - & 一 \\
\hline
\end{tabular}

(P42の下へつつ’く) 
ものがかなり高い值を示している。したがって PE 漂 白反応は単に炭水化物特にペントザンの保持量が高い のみならず，その作用が温和であり，質的にもかなり 変化が少なく，もとの重合度を維持せしめているもの と推定される。

\section{むす び}

過酢酸を使ってUKP を漂白し，対照試料として5 段漂白パルプを作製し，比較しながら，その特徴を検 討した。その結果次のような結果が得られた。

1. $\mathrm{PE}$ 漂白パルプは収量, 強度ともにすぐれてい るが，色戻りのやや激しい欠点を持っている。

2. PE 漂白は, ただ 1 回の処理で中白色度のパル プを与える。漂白をより効果的汇行ならにはパルプの 含水量は小さい方が望ましい。また漂白条件としては 高濃度, 短時間処理のものがパルプの品質技よび熱経 済の点からも望ましい。

3. PE 漂白パルプの化学分析の結果, へミセルロ
ースの保持が良好で重合度もかなり高いことを示した。<smiles>[Y]</smiles>

1）河野, 坂井, 近藤：紙パ技誌 19, 27 (1965)

2）畠山, 中野, 右田: 第 9 回リグニン化学討論要 旨集, p. 47 (1964)

3) 石川, 沖: 同上, p. 52

4) Tappi 47, 104A (1964) No. 10

5) R. H. MacClaren, F. L. Well, J. V. Rosequist and D. F. Ingerick: Tappi 45, 789 (1962)

6) Tappi Monograph No.27: The bleaching of pulp (1963)

7) S. W. Atkins and D. H. Hamly: Pulp \& Paper Mag. Can., 85, T-179 (1964)

8) W. H. Rapson: Tappi 39, 284 (1956)

9）戸田：紙パ技誌，18, 537 (1964)

10) I. H. Spinner: Tappi 45, 495 (1962)
(P 52 よりつづく)

(4) ブラシ式エアナイフ式拈よびスムージングロール 式のコーティングマシン用のコーティング材料の調 製法とその流動性はチャンピオンマシンコーティン グ用の場合と同様であるが，その固形分含量と粘度 を若干減らす場合が多い。塗被量はチャンピオンコ ーティングの場合ほぞ固形分に規制されず固形分は できるだけ高くする必要がある。それ故カゼインカ ラーはラテックスを配合すると粘度の点で有利とな る。コーティングにはピグメントとしてクレーだけ 用いてもよく，このようなコーティングにはチャン ピオンコーティング用に例示した配合のものを使用 することができる。しかし高級アート紙用には，ピ グメントにクレーとサチンホワイトまたはクレー硫 酸バリウムとサチンホワイトを組合わせて用いるこ とがある。つぎに示す配合はレタープレス印刷用ア 一ト紙向けのカラー配合例で，オフセット印刷用の ものに対してはバインダーの配合量を引き上げる必 要がある。

\section{乾燥重量 (部)}

$ク \quad$ - $80 \quad 60$

炭酸カルシウム $\quad 20 \quad 40$

カルゴン $\quad 0.50 .5$

カゼ イ ソ

ラテックス 446

全固形分 (\%) 約 $40 \%$

オフマシンコーティングによるアート紙は通常カゼ インペースのカラーが用いられるが，ラテックスに
澱粉を配合したものを用いることもでさる。 乾燥重量 (部)

$\begin{array}{llc}\text { ク } & \text { レ } & 60 \sim 80 \\ \text { 炭酸カルシウム } & 40 \sim 20 \\ \text { カル シ ン } & 0.5 \\ \text { 溉 } & \text { 粉 } & 15 \\ \text { ラテックス } & 8 \\ \text { 全固 形 分 } \% & 36 \sim 38 \%\end{array}$

(5) その他のコーティング法

上記のほかトレーリング・ブレードコーターとコ ンバインドロックスコーターの 2 種のコーターがー 般用いら礼てきた。

(6) 板紙のコーティング あらゆる種類の板紙のコーティングにラテックス は用いられ一般につぎのような配合のものを用いて よい成績があがっている。

乾燥重量 (部)

$\begin{array}{lcc}\text { ク } & - & 100 \\ \text { カルゴン } & 0.5 \\ \text { カゼイ ン } & 12 \\ \text { ラテックス } & 6 \\ \text { 全 固 形 分 } & 40 \%\end{array}$

この種のカラーの固形分は $40 \%$ あるが，それぞ れの仕様沁応じて增減できる。塗布量が $35 \sim 40 \mathrm{~g} / \mathrm{m}^{2}$ の場合は上記配合のものを用いてェアーナイフ法で 1 回コートで十分であるが， $40 \mathrm{~g} / \mathrm{m}^{2}$ 以上の場合に はダブルコートが必要である。

以上 